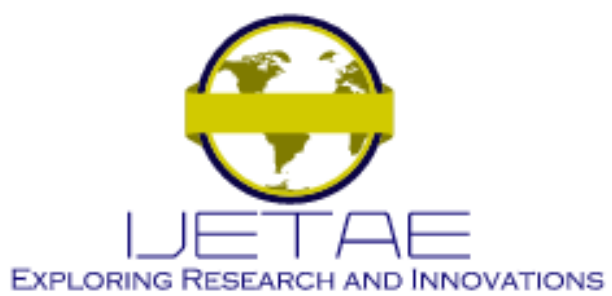

International Journal of Emerging Technology and Advanced Engineering

Website: www.ijetae.com (E-ISSN 2250-2459, Scopus Indexed, ISO 9001:2008 Certified Journal, Volume 12, Issue 01, January 2022)

Manuscript Received: 08 December 2021, Received in Revised form: 06 January 2022, Accepted: 10 January 2022

DOI: $10.46338 /$ ijetae0122_05

\title{
Integration of Data Flows of the Construction Project Life Cycle to Create a Digital Enterprise Based on Building Information Modeling
}

\author{
Akselrod Roman ${ }^{1}$, Shpakov Andrii ${ }^{2}$, Ryzhakova Galyna ${ }^{3}$, Tetyana Honcharenko ${ }^{4}$, Chupryna Iurii ${ }^{5}$, Shpakova Hanna ${ }^{6}$ \\ ${ }^{I}$ Vice-Rector for Academic Work and Regional Development, Kyiv National University of Construction and Architecture, 31, \\ Povitroflotsky Avenue, Kyiv, 03037, Ukraine \\ ${ }^{2}$ Vice-Rector for Educational and Methodical Work, Kyiv National University of Construction and Architecture, 31, \\ Povitroflotsky Avenue, Kyiv, 03037, Ukraine \\ ${ }^{3,5}$ Department of Management in Construction, Kyiv National University of Construction and Architecture, 31, Povitroflotsky \\ Avenue, Kyiv, 03037, Ukraine \\ ${ }^{4}$ Department of Information Technologies of Design And Applied Mathematics, Kyiv National University of Construction and \\ Architecture, 31, Povitroflotsky Avenue, Kyiv, 03037, Ukraine \\ ${ }^{6}$ Department of Construction Technologies, Kyiv National University of Construction and Architecture, 31, Povitroflotsky \\ Avenue, Kyiv, 03037, Ukraine
}

\begin{abstract}
This study is devoted to the problem of digital transformation in the construction industry. To solve the proposed emerging approach for integrating information flows based on Building information modeling (BIM). This research describes the advanced methodology for creating a unified information model in construction, which combines architectural, design, engineering, cost and depreciation models of a construction object, raises a number of problems of reorganizing business processes at enterprises. The novelty of the research lies in the model of adapted common data environment based on life cycle of a construction project by stages of implementation and emergence of information. The proposed architecture is a platform for intelligent parametric modeling as intelligent CAD, which allows linking all elements of the model "Digital Enterprise".The result of the study is a conceptual mechanism for improving the efficiency of enterprise management processes based on the architectural approach in terms of digitalization of construction. Emerging technology in the study is the architecture of the intelligent decision support system in construction based on 5D BIMtechnology and Digital Enterprise. The main advantage of the proposed approach is the possibility of multiple reuse of information by all participants in the development and implementation of an investment and construction project without changes and distortions of data about the construction object.
\end{abstract}

Keywords - Building Information Modeling, BIM, Digital Enterprise, Common Data Environment, life cycle of construction project, digitalization of construction

\section{INTRODUCTION}

Building information modeling (BIM) is an approach to the construction, equipment, maintenance and repair of a building (to managing the life cycle of an object), which involves the collection and integrated processing in the design process of all architectural, design, technological, economic and other information about a building with all its interconnections and dependencies, when the building and everything related to it are considered as a single object [1].

The main advantages of BIM models are their dynamism, that is, when individual elements of the model are changed, the data and parameters of related documents are automatically updated [2].

BIM-modeling in the tasks of construction and architecture, but explain its specifics associated with the variety of financial and economic activities of its enterprises and the peculiarities of the production cycle, in which a significant number of projects are at various stages of implementation.

The aim of the study was to optimize the management of information flows (IF) in construction production, which makes it possible to increase the efficiency of management through the use of mechanisms and tools for creating a unified information environment and providing a basis for multi-user access to data and the implementation of effective teamwork. 


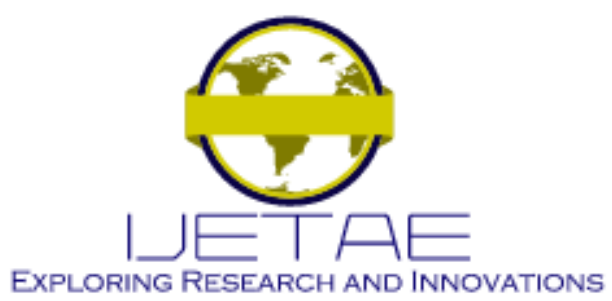

International Journal of Emerging Technology and Advanced Engineering

Website: www.ijetae.com (E-ISSN 2250-2459, Scopus Indexed, ISO 9001:2008 Certified Journal, Volume 12, Issue 01, January 2022)

In the course of the research, the following tasks were formulated and solved:

1. internal information audit of construction production;

2. analysis of existing business processes and approaches to IP management;

3. defining the goals and objectives of using information modeling in construction production;

4. analysis of individual entrepreneurs in the activities of a construction organization

5. development of an integration methodology and a scheme for the interaction of data flows based on BIM.

\section{Literature ReVIEW AND PRoblem STATEMENT}

At the present stage of development of the project management methodology, on the principles of which investment and construction activities are built, in the context of cost optimization and the choice of high-tech solutions, approaches to managing such key parameters as content, timing and cost throughout the entire life cycle of a capital construction object become relevant.

For example, such methodologies as Total Cost Management (TCM), Product Lifecycle Management (PLM), Life Cycle Costing (LCC) [3-5] have been actively developed in the world. Together with BIM, they form a common innovative approach to information modeling and building lifecycle management called Building Lifecycle Management (BLM).

At the same time, the long-term experience of foreign and domestic companies testifies to the relevance and effectiveness of the implementation of information modeling technologies at the design and construction stages. However, the world has not yet gained sufficient experience with digital building models to apply BIM at the operational stage. The duration of the phase of operation of a capital facility is on average 10-20 times longer than the period of its construction, and the life cycle cost is 5 to 7 times higher than the cost of the initial investment and is three times higher than the cost of construction [6]. For these reasons, the operational phase is the most significant in terms of duration and the tasks of using information models to optimize the life cycle costs of a capital facility.

The main purpose of the operational phase is the material, technical and commercial management of the property in the interests of the owner.
It is the owner of the facility that is the person who is objectively interested in obtaining comprehensive, complete, relevant and reliable information about the facility, accumulated in a single information model (BIMmodel) by all participants in the investment and construction project.

The main directions implemented by the owner (or management companies) of the real estate object in the operational phase are [7-12]:

- Facility Management (FM) is the infrastructure management, including the processes of maintenance and operation of the property, ensuring its physical preservation and trouble-free operation.

- Property Management (PM) is a commercial and administrative-legal management of a real estate object aimed at obtaining maximum income by the owner while optimizing costs.

- Asset Management (AM) is the management of a real estate object as an asset, associated with the implementation of long-term goals of its development and maximization of value.

In the context of the transition of the construction industry to a digital environment, an active search for innovative and high-tech ways of development, it becomes an objective necessity for property owners to use digital methods and tools that correspond to the tasks of FM, PM and AM. Thus, the BIM model formed at the design and construction phases of the life cycle of a capital facility must also meet the requirements of the operational phase.

Figure 1 in [2] shows famous building life cycle with various components of information and material processes.

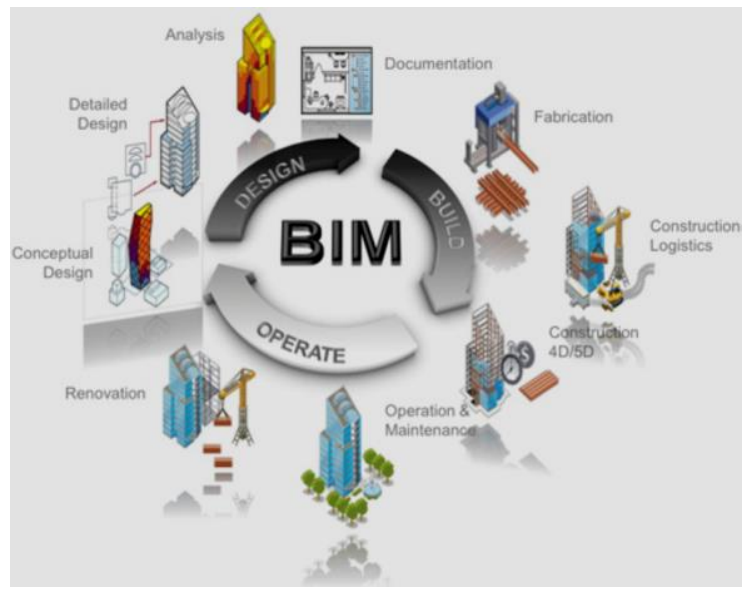

Fig. 1 Building Life Cycle showing various components of information and material processes [2] 


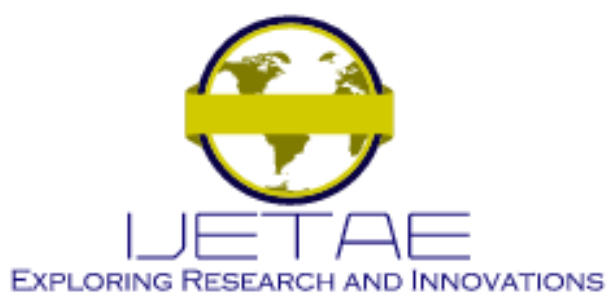

International Journal of Emerging Technology and Advanced Engineering

Website: www.ijetae.com (E-ISSN 2250-2459, Scopus Indexed, ISO 9001:2008 Certified Journal, Volume 12, Issue 01, January 2022)

Based on the analysis of scientific sources [13-21] Table 1 summarizes the basic requirements that a digital building model must meet in order to effectively manage it in the operational phase in the aspect of an integrated approach to implement the tasks of FM, PM and AM.

TABLE I

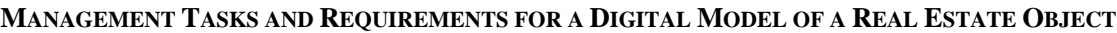

\begin{tabular}{|c|c|c|}
\hline Directions and tasks & Digital model requirements & Applied digital methods \\
\hline $\begin{array}{l}\text { Material and technical management - Facility } \\
\text { Management: } \\
\text { - ensuring the smooth functioning of engineering } \\
\text { systems; } \\
\text { - modernization and development of infrastructure; } \\
\text { - ensuring the security and safety of the facility; } \\
\text { - organization of cleaning services; } \\
\text { - prevention and elimination of the consequences of } \\
\text { emergency situations }\end{array}$ & $\begin{array}{l}\text { - } \text { orderly secure storage of } \\
\text { information as part of a } \\
\text { digital model throughout the } \\
\text { entire life cycle of an asset; } \\
\text { - availability of operational } \\
\text { documentation with } \\
\text { information about design, } \\
\text { engineering and material } \\
\text { elements of the facility for } \\
\text { further scheduled and major } \\
\text { repairs, } \\
\text { maintenance; } \\
\text { the model should be } \\
\text { "cleared" of information from } \\
\text { the construction stage (for } \\
\text { example, on equipment and } \\
\text { temporary structures) }\end{array}$ & $\begin{array}{l}\text { - } \text { automated control systems } \\
\text { for equipment maintenance } \\
\text { and repair; } \\
\text { - } \text { performance monitoring } \\
\text { systems; } \\
\text { - } \text { simulation of emergency } \\
\text { situations; Big-data; } \\
\text { - laser scanning (in the } \\
\text { absence of a digital model of } \\
\text { the building); } \\
\text { - cloud technologies; } \\
\text { - "Digital twins" of the } \\
\text { building; } \\
\text { - Smart homes; } \\
\text { - automated metering systems } \\
\text { for energy and other } \\
\text { resources consumption }\end{array}$ \\
\hline $\begin{array}{l}\text { Commercial management } \\
\text { 1. Property Management: } \\
\text { - positioning and promotion of an object on the } \\
\text { market (for commercial real estate) } \\
\text { - operational management; } \\
\text { - administrative and legal management of the object; } \\
\text { - providing financial, economic and legal document } \\
\text { flow; } \\
\text { - management of lease relations, brokerage (for } \\
\text { - commercial real estate); } \\
\text { 2. Asset Management: } \\
\text { - strategic financial management and refinancing; } \\
\text { - strategic planning to preserve and maximize the } \\
\text { value of the property; } \\
\text { - inventory and assessment; } \\
\text { - accounting for depreciation and amortization; } \\
\text { - economic modeling and forecasting. }\end{array}$ & $\begin{array}{l}\text { - providing stakeholders with } \\
\text { search and analysis tools } \\
\text { required } \\
\text { - data and documents; } \\
\text { - Formation of reports on the } \\
\text { content; } \\
\text { - provision of controlled access } \\
\text { to data in the digital model } \\
\text { for interested parties; } \\
\text { - synchronization of technical } \\
\text { and commercial information } \\
\text { in a single digital model; } \\
\text { - integration with the business } \\
\text { processes of the operating } \\
\text { organization. }\end{array}$ & $\begin{array}{l}\text { - } \text { electronic trading platforms; } \\
\text { - smart contracts; } \\
\text { - blockchain; } \\
\text { - "digital twins" of the } \\
\text { building; } \\
\text { - augmented reality; } \\
\text { - automated document } \\
\text { - } \text { simanagement systems; } \\
\text { - } \text { financial flows; } \\
\text { - automated logistics systems; } \\
\text { automated accounting } \\
\text { and receipts. }\end{array}$ \\
\hline
\end{tabular}

In addition, the operational phase of the life cycle of a capital facility is mainly operational activity with periodic inclusion of investment for the implementation of development projects, overhaul and reconstruction of the property.
In this regard, the BIM model must also meet the requirements of integration with the main systems used by the owner in the operational management during the operational phase: 


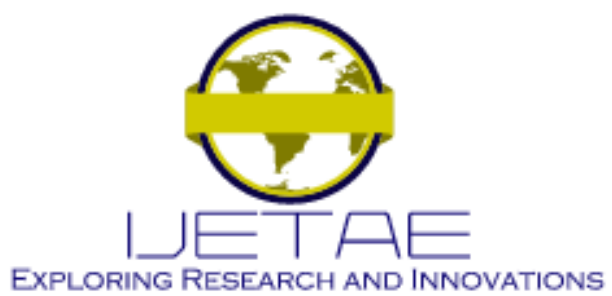

International Journal of Emerging Technology and Advanced Engineering

Website: www.ijetae.com (E-ISSN 2250-2459, Scopus Indexed, ISO 9001:2008 Certified Journal, Volume 12, Issue 01, January 2022)

- Computer-Aided Facilities Management (CAFM) is intended for capital construction object management, which regulates the processes of transferring design information to object-oriented systems of operational documentation based on the use of COBie tables;

- Computerized Maintenance Management System (CMMS) is intended for routine maintenance and repair of equipment;

- Building Automation System (BAS) is intended for centralized control of engineering systems in order to optimize energy consumption and maintenance costs;

- Geographic Information System (GIS) is necessary for geolocation of an object and its engineering systems in an urban environment;

- Enterprise Resource Planning (ERP) is necessary for management, planning and accounting of monetary and human resources;

- Records Management (RM) is necessary for effective coordination of project management.

The resulting digital building information model, which fully meets the objectives of the operational phase, is an effective management tool. Such a "digital twin" always carries up-to-date information about the state of engineering systems and equipment, the timing of their replacement or maintenance.
This allows planning and carrying out timely repairs, ensuring the efficient operation of the entire infrastructure of the building during the entire operational period, as well as ensuring safety in the event of natural disasters, fires, terrorist attacks, etc. [22].

In the process of use, the digital prototype continues to be filled with new relevant information, for example, when carrying out renovation or major repair projects. This application of the information model at the operational stage can be considered its highest point of development.

\section{RESEARCH METHODOLOGY}

The methodology for creating a unified information model in construction, which combines architectural, design, engineering, cost, and subsequently, depreciation models of a construction object, raises a number of problems of reorganizing business processes at enterprises in the construction industry.

To solve it, it is necessary to train specialists in the construction industry with new competencies who can work in a project team in order to minimize costs throughout the entire life cycle of a building and structure:

Figure 2 shows life cycle of a construction project by stages of implementation and emergence of information.

\begin{tabular}{|c|c|c|c|c|c|}
\multicolumn{2}{c}{ Idea } & Feasibility & Project stage & Working stage & Construction \\
\hline Designer & & & & & \\
\hline Contractor & & & & \\
\hline Customer & & & & \\
\hline Builder & & & & \\
\hline Information & & Information creation & Updating information Use of information \\
\hline
\end{tabular}

Common Data Environment

Fig. 2 Life cycle of a construction project by stages of implementation and emergence of information 


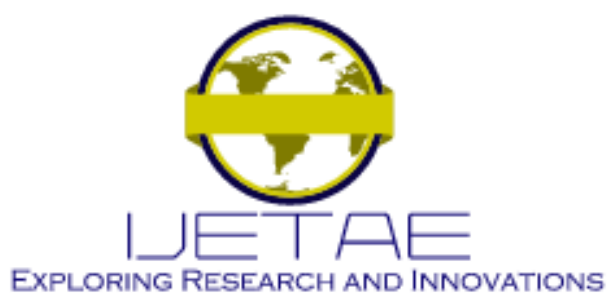

International Journal of Emerging Technology and Advanced Engineering Website: www.ijetae.com (E-ISSN 2250-2459, Scopus Indexed, ISO 9001:2008 Certified Journal, Volume 12, Issue 01, January 2022)

To build an effective management system, it is required to conduct a detailed study of construction production as a system of flows: material, financial, management and information. Flows accompany different processes of construction production: workflow (control and information flows), logistics (material flows and financial and information flows reflecting them), technology (material and financial and information flows reflecting them), marketing (material, financial, information and management). In the study of information flows, a general picture of the construction industry is formed.

For effective management of information flows in the construction industry, it is necessary that information be systematized, structured, and standardized. Most of the information circulating in construction is systematized, but it requires structure (for example, in Excel tables). In the process of transferring it, it is required to determine the authorship, to analyze who is entering the information and why, and to interact directly to obtain reliable information from the original source.

The study of information flows includes checking for internal and external information. When forming the information space of the construction process, one can note weak interaction between different departments in the design process, frequent duplication of information, lack of compatibility of drawings made by various design companies.

Figure 3 shows adapted common data environment for integrating information flows based on BIM.

Therefore, it is proposed to use an information model to create a unified information environment for construction production, which makes it possible to link basic data, a graphical display of objects, and their description from the standpoint of the main production services and create an object-oriented archive of documents. To achieve the maximum effect from the introduction of the information model, it is necessary to cover the maximum stages of the life cycle of a construction object, broader use of information, and building processes in such a way that the information entered is reused for different purposes.

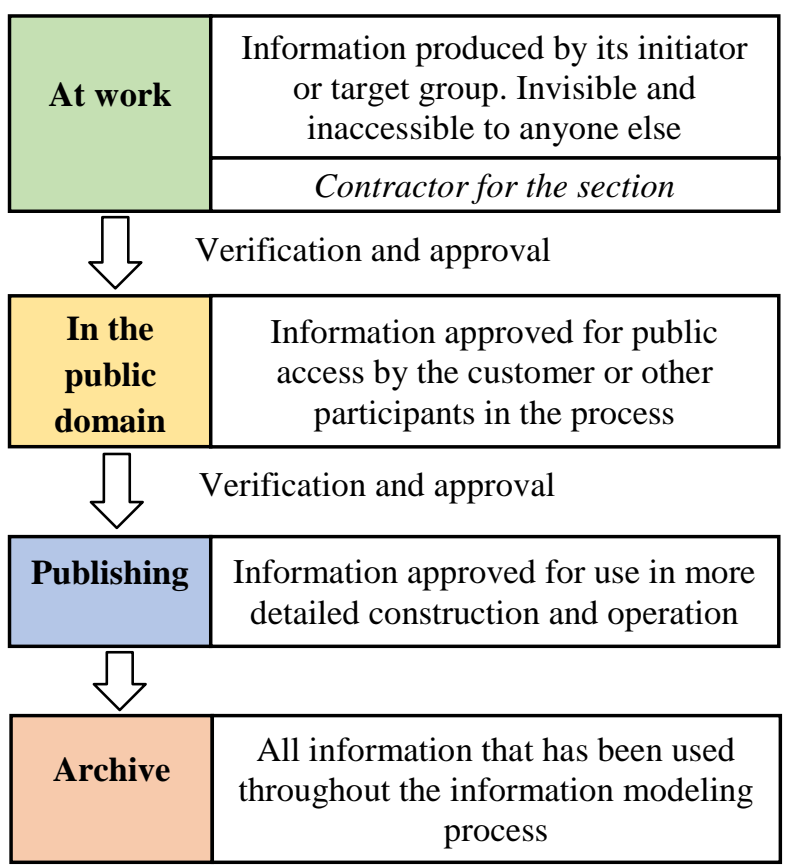

Fig. 3 Adapted Common Data Environment for integrating information flows based on BIM

Building Information Modeling (BIM) tasks. The basic principles of the information approach in construction were formulated in article [25]:

- 3D-model of the project is created by architects, engineers, designers jointly; you can get drawings from the model;

- each object has its own set of data and parameters;

- it is possible to include time dependencies in the model [23-25].

At the same time, the risk of errors between different sections of project documentation is minimized, decisionmaking is accelerated, the amount of information entered is reduced and it becomes possible to avoid errors associated with the human factor. 


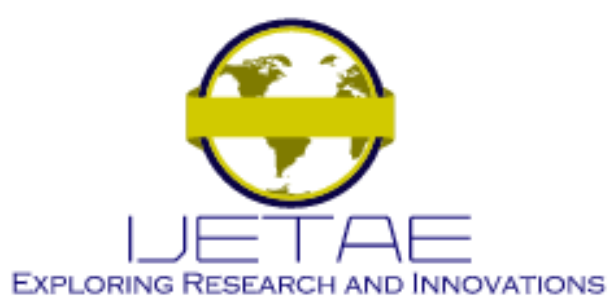

International Journal of Emerging Technology and Advanced Engineering Website: www.ijetae.com (E-ISSN 2250-2459, Scopus Indexed, ISO 9001:2008 Certified Journal, Volume 12, Issue 01, January 2022)

For effective interaction with business partners, it is necessary to ensure the flow and transmission of information in acceptable formats, in addition, a dialogue with organizations to optimize the exchange of information is necessary, and this is a business imperative.

Methodology for integrating information flows based on BIM. It is proposed to create a unified information flow management system based on BIM. As a rule, departments have their own automation and control systems, optimized for specific tasks. But local systems that prepare materials well for external organizations (reports for the tax office, various drawings, engineering calculations, etc.) do not increase the efficiency of the management process. When analyzing these materials, managers spend a lot of time and do not always get the desired results for an integrated assessment of production and operational adoption of tactical and strategic decisions [26]. It is proposed to distinguish two main information structures in construction is a system for automating accounting and management and a BIM system.

Figure 4 shows model for integrating information flows based on BIM in the construction Enterprise.

ERP-system (Enterprise Resource Planning System) is an enterprise resource planning system. ERP is being implemented to improve the quality of planning, reduce inventory, increase the flow rate and turnover, increase the profitability of projects, and produce on time. The use of ERP in construction is difficult due to the length of the production cycle, which involves a huge number of documents, orders, deliveries, contracts, etc.

In a unified environment for a construction project, the ERP system is linked through information flows by the components of a BIM system is a system for designing and calculating architecture, structures and engineering networks, an estimate system and scheduling, as well as a common database (Fig. 4).

The database is a common repository that links design engineering models and acts as a transmitter of design decisions into cost and financial decisions and a data accumulator for the analytical decision-making center. Having a database, we can choose from the list of available templates what we need with optimal performance for the given parameters. And choose the best option in terms of cost and production logistics.

The data exchange strategy in accordance with the software allows the integration of structural analysis into the 3D model.
The transfer of parametric information of the geometry of objects is possible through the use of Application Programming Interfaces (API), controlled by programming languages such as VBA, C\#, etc.

The exchange of data between CAD and software for structures or engineering networks, based on files in open formats IFC, gbXML, is still problematic due to the lack of unification of different software vendors and different types of files. The model on a single platform Bentley, Autodesk has the advantage [27]. The proprietary closed file format allows data exchange between applications belonging to a single line, which ensures efficient coordination of information.

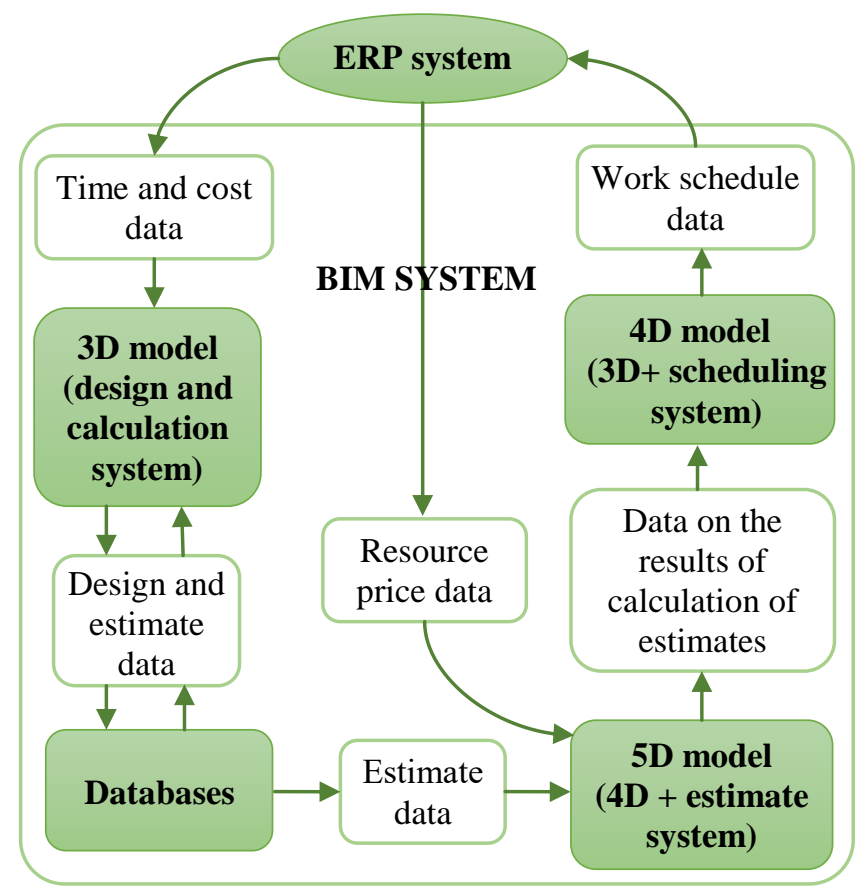

Fig. 4 Model for integrating information flows based on BIM

The construction scheduling system includes the choice of construction technology, the definition of work tasks, the assessment of the required resources, the calculation of task durations and the determination of the sequence of these tasks [22]. When creating standard projects, it is convenient to use previously created templates so as not to duplicate work. Automatic linking of 3D model components with calculated data and work parameters to create a graph completes the 4D model creation. 


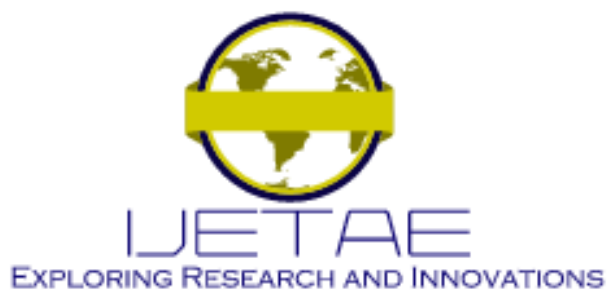

International Journal of Emerging Technology and Advanced Engineering Website: www.ijetae.com (E-ISSN 2250-2459, Scopus Indexed, ISO 9001:2008 Certified Journal, Volume 12, Issue 01, January 2022)

The construction schedule can be developed in Primavera and in Microsoft Project. Next, you need to prepare a schedule for import, for example, in Navisworks, making it as detailed as possible [28-30].

Using plugin in BIM, it is possible to calculate estimates by combining design and audit programs into the information model using APIs from different applications. Through the software environment of the database, communication with the $3 \mathrm{D}$ model is carried out to transfer the results of the estimated calculations. The generated estimate assignment is transferred to the 4D model. At the output of the estimate system, a package of documents for the object is formed. Development of an estimate section is possible in Nemetschek Allplan, Autodesk Revit.

\section{RESUlTS AND DiscusSiON}

Based on the proposed methodology for building the architecture of the enterprise and the identified role of information technology in its formation, as a result of the study proposed a conceptual mechanism for improving the efficiency of enterprise management processes, which is presented in Fig. 5.

The implementation of the mechanism is based on the process of transition from the model of the enterprise "as is" to a promising model of enterprise architecture ("to be"), on the basis of which the enterprise development program is developed.
The model of enterprise architecture reflects not only the main and auxiliary business processes of the enterprise in their close relationship with the IT infrastructure, but also a number of critical for business entities, such as capabilities, business model, non-process activities (projects, cases), knowledge, informal structure, etc.

In fig. 6 presents the basic architecture of the intelligent decision support system in the field of construction based on 5D technology.

The proposed architecture is, in essence, a platform for intelligent parametric modeling (intelligent CAD), which allows to link all elements of the model "Digital Enterprise" with dependencies that describe their interaction with the contextual mechanism of change. All elements of such a model are connected by dependencies automatically.

The agreed change of the model resembles the change of the cells of the spreadsheet, the values of which are given by formulas. Changes in any cell are automatically displayed throughout the table. Spreadsheet formulas allow you to automate calculations based on changes. The proposed platform of intelligent parametric modeling behaves similarly, allowing to dynamically synthesize the most effective design solutions of a complex model of construction objects. 


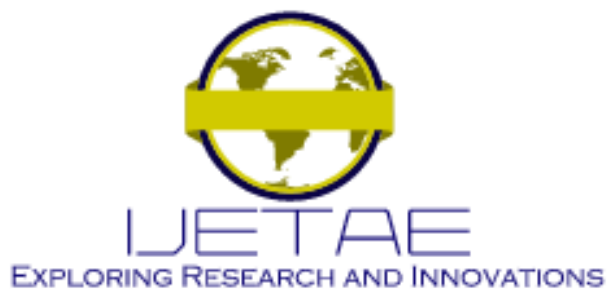

International Journal of Emerging Technology and Advanced Engineering

Website: www.ijetae.com (E-ISSN 2250-2459, Scopus Indexed, ISO 9001:2008 Certified Journal, Volume 12, Issue 01, January 2022)

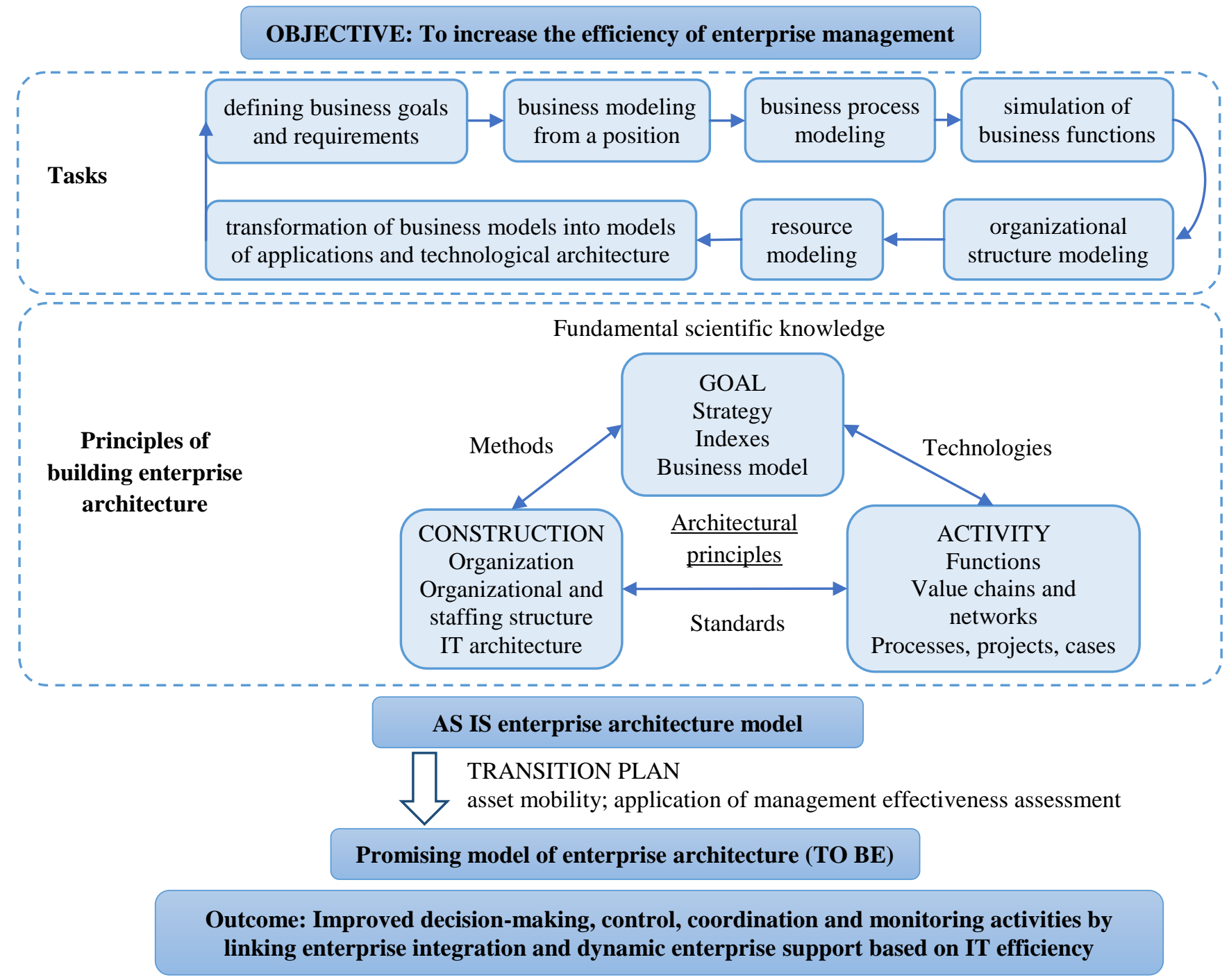

Fig. 5 Conceptual mechanism for improving the efficiency of enterprise management processes based on the architectural approach in terms of digitalization of construction.

The main principle of creating a common data environment is to develop a coding classification system that will allow transparent access to any type of information located in the relevant databases needed for decision-making.

The difficulty of such integration is to show the possibility of using different information technologies in one particular organization and without interfering in its activities, to make demands on the results of their activities.
Figure 7 shows structure of INTEGRATOR 5D modeling platform for decision-making for creation "Digital Enterprise". It has eight components: four IT and four databases. This is basis for choosing hardware and software tools for digitalization of construction enterprise. 


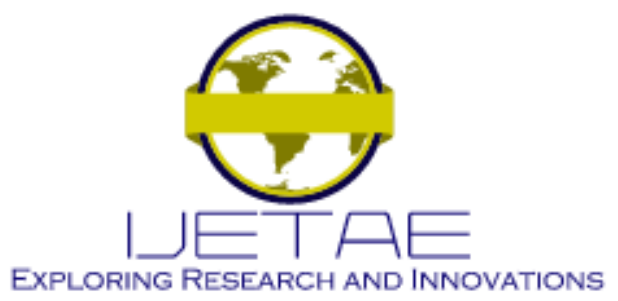

International Journal of Emerging Technology and Advanced Engineering

Website: www.ijetae.com (E-ISSN 2250-2459, Scopus Indexed, ISO 9001:2008 Certified Journal, Volume 12, Issue 01, January 2022)

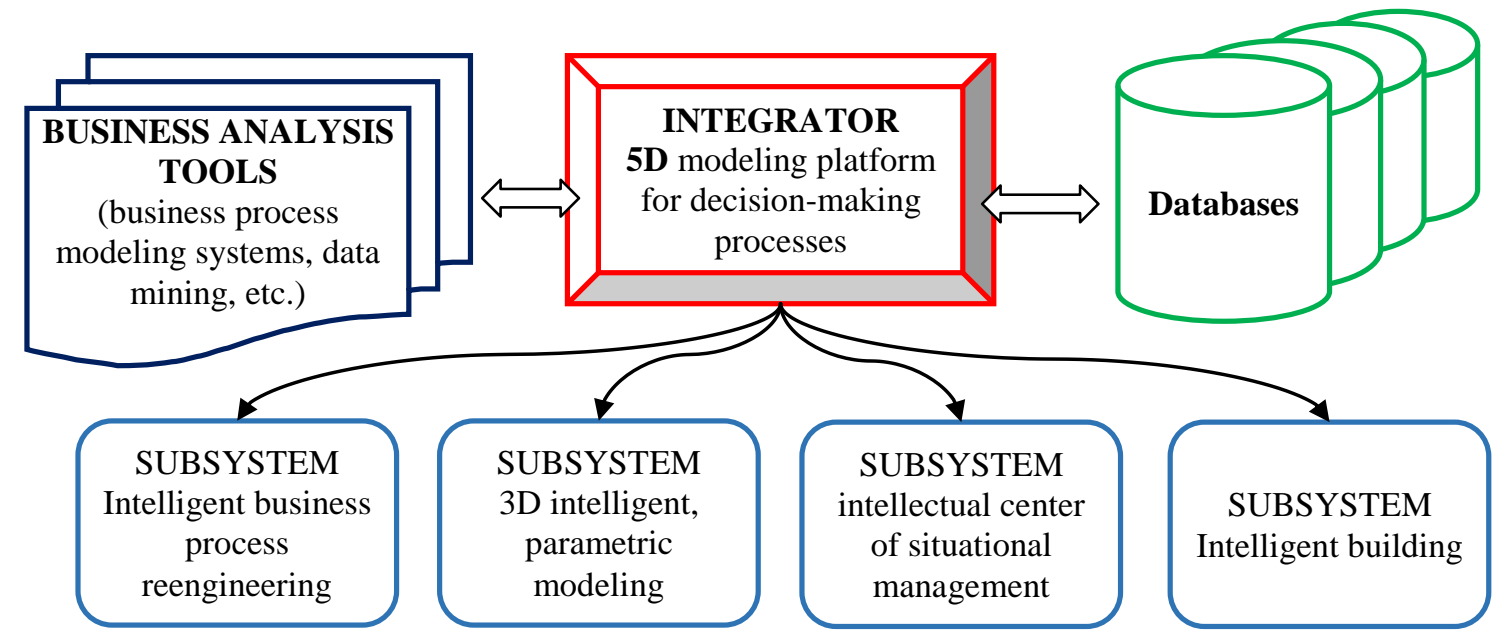

Fig. 6 Basic architecture of intelligent decision support system in the field of construction based on BIM-technology and "Digital Enterprise"

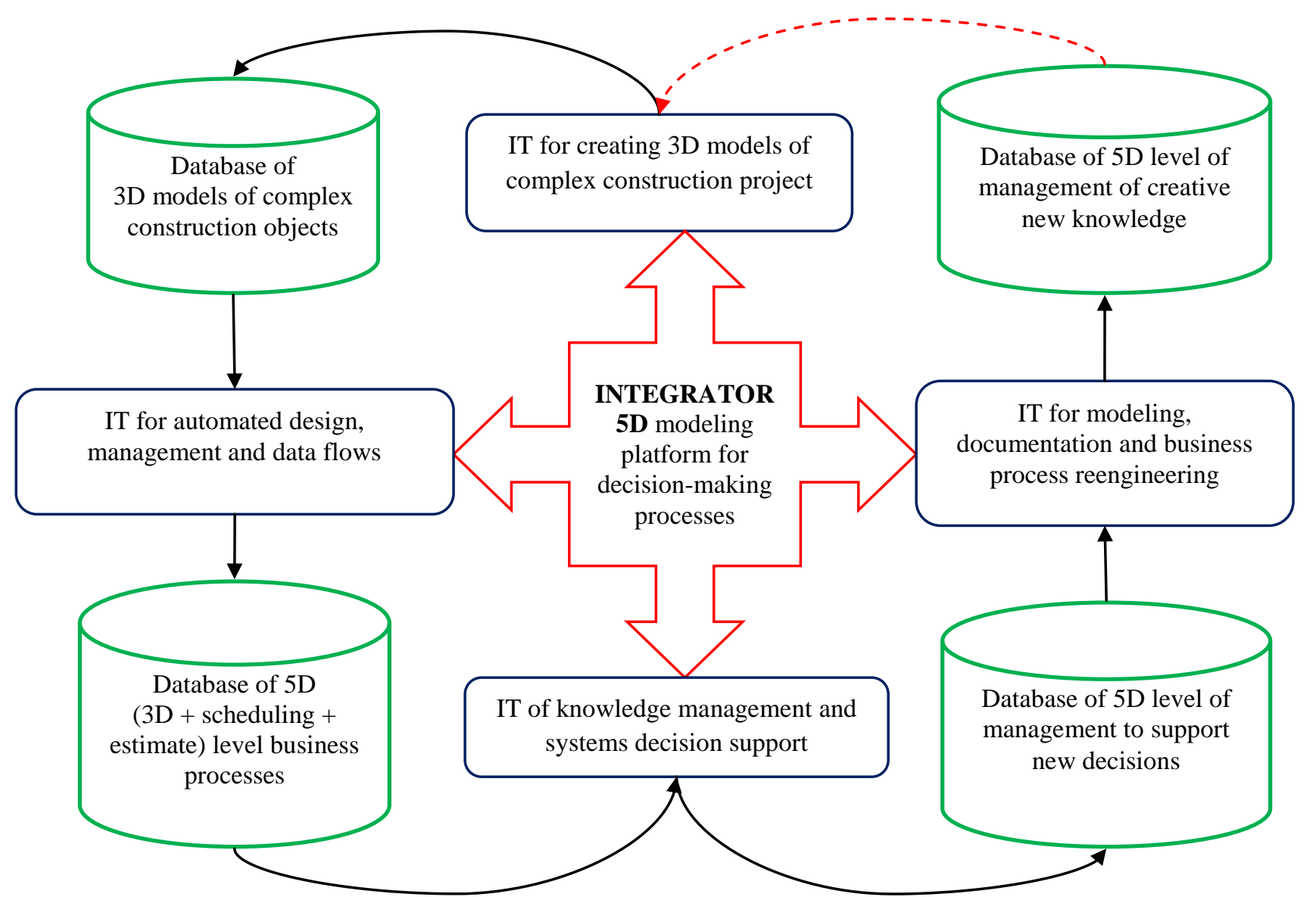

Fig. 7 Structure of INTEGRATOR 5D modeling platform for decision-making 


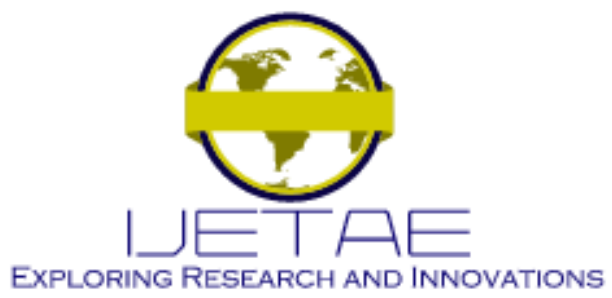

\section{International Journal of Emerging Technology and Advanced Engineering Website: www.ijetae.com (E-ISSN 2250-2459, Scopus Indexed, ISO 9001:2008 Certified Journal, Volume 12, Issue 01, January 2022)}

\section{CONCLUSIONS}

The study confirms the need for the active use of BIM technologies, the implementation of which will increase labor productivity, reduce costs and obtain tangible economic benefits in the implementation of construction projects. The ways to solve the problems mentioned in the article, standing on the way of developing BIM technologies, consists in the exchange of experience, in close interaction between various stakeholders. They are software developers, builders, architects, designers, designers, operators and specialists in related industries.

In the study, the analysis of information management in the preparation of construction production was carried out, the goals of creating BIM were determined and a methodology for the interaction of information flows based on BIM was proposed.

When applying BIM technology, specialists have to know: how to jointly make a project, what set of elements, what set of properties and parameters to use, how to use them inside their CAD information space (information systematization). In addition, for successful joint teamwork on a project, specialists have to follow the rules for naming and storing project files established in the enterprise (information standardization) and create and use wellstructured information.

The main advantage of the proposed approach is the possibility of multiple reuse of information by all participants in the development and implementation of an investment and construction project without changes and distortions of data about the construction object. This will lead to a reduction in lost working time, a decrease in the payroll due to a decrease in labor costs for information processing, savings due to a decrease in inventories, a reduction in construction time and a decrease in work in progress.

\section{REFERENCES}

[1] M. Arslan, Z. Riaz, S. Munawar.(2017). Building Information Modeling (BIM) Enabled Facilities Management Using Hadoop Architecture. 2017 Proceedings of PICMET '17: Technology Management for Interconnected World, Portland, USA.

[2] R.Sacks, C.Eastman, G. Lee, P. Teicholz. (2018). BIM Handbook: A Guide to Building Information Modeling for Owners, Designers, Engineers, Contractors, and Facility Managers, 3rd ed.; John Wiley \& Sons: Hoboken, NJ, USA, p. 688

[3] T. Honcharenko, Y. Chupryna, I. Ivakhnenko, M. Zinchenco and T. Tsyfra. "Reengineering of the Construction Companies Based on BIM-technology", International Journal of Emerging Trends in Engineering Research, 8(8), August 2020, pp. 4166-4172 https://doi.org/10.30534/ijeter/2020/22882020
[4] K. Kyivska, Y. Borodavka, S. Tsiutsiura, T. Honcharenko. (2021). Information technology of automation of life cycle of construction objects. Turkish Journal of Computer and Mathematics Education, Vol.12, No.13, 152-158, https://turcomat.org/index.php/turkbilmat/article/view/8267/6445

[5] Riabchun Y., Honcharenko T., Honta V., Chupryna K., Fedusenko O. (2019). Methods and means of evaluation and development for prospective students' spatial awareness. International Journal of Innovative Technology and Exploring Engineering, 8(11), pp. 4050$4058 . \quad$ https://www.ijitee.org/wpcontent/uploads/papers/v8i11/K15320981119.pdf

[6] S.A.Biancardo, N. Viscione, A. Cerbone and E. Dessì.(2020). BIMBased Design for Road Infrastructure: A Critical Focus on Modeling Guardrails and Retaining Walls. Infrastructures, 5, 59, https://doi.org/10.3390/infrastructures5070059

[7] T. Honcharenko, O. Terentyev, O. Malykhina, I. Druzhynina, I. Gorbatyuk. (2021). BIM-Concept for Design of Engineering Networks at the Stage of Urban Planning. Int. Journal on Advanced Science, Engineering and Information Technology, 11(5):13061312,http://insightsociety.org/ojaseit/index.php/ijaseit/article/view/1 3687.

[8] Mihaylenko V., Honcharenko T., Chupryna K., Liazschenko T. (2021). Integrated processing of spatial information based on multidimensional data models for general planning tasks. International Journal of Computing, vol. 20 (1), 55-62. https://doi.org/10.47839/ijc.20.1.2092

[9] A. Kuchansky, Y. Andrashko, A. Biloshchytskyi, O. Danchenko, O. Ilarionov, I. Vatskel, T. Honcharenko. (2018). The method for evaluation of educational environment subjects' performance based on the calculation of volumes of M-simplexes. Eastern-European Journal of Enterprise Technologies, 2 (4-92), pp. 15-25, http://journals.uran.ua/eejet/article/download/126287/125235

[10] D. Ryzhakov, O. Dikiy, M. Druzhynin, H. Petrenko, T. Savchuk. (2020). Innovative tools for management the lifecycle of strategic objectives of the enterprise-stakeholder in construction. International Journal on Emerging Trends in Engineering Research, 8(8), pp. 4526-4532. https://doi.org/10.30534/ijeter/2020/78882020

[11] A. D'Urso, V. Cutraro, C. Catania, F. Rapisarda, G.Garaffo, M.Calì.(2019). Closed Cycle Drying Process To Retrain Industrial Sludge into Construction Products", International Journal on Advanced Science, Engineering and Information Technology, 9(6), pp. $1783-1788$

[12] A. Hedzyk, A. Silveistr, S. Karpliuk, L. Manchulenko, N. Bilyk, L. Prokopenko. (2021). Aspects of Information Support of the Learning Process. International Journal of Emerging Technology and $\begin{array}{llll}\text { Advanced } & \text { Engineering, } & 11 & \text { (10), }\end{array}$ https://doi.org/10.46338/ijetae1021_06

[13] Krivenko P., Petropavlovskyi O., Kovalchuk O., Lapovska S., Pasko A. (2018). Design of the composition of alkali activated portland cement using mineral additives of technogenic origin. EasternEuropean Journal of Enterprise Technologies, 4(6-94), 6-15.

[14] Terenchuk S., Yeremenko B., Sorotuyk T. (2016). Implementation of intelligent information technology for the assessment of technical condition of building structures in the process of diagnosis. EasternEuropean Journal of Enterprise Technologies, 5 (3-83), pp. 30-39. 


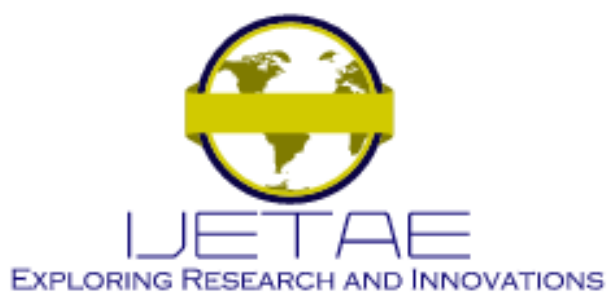

International Journal of Emerging Technology and Advanced Engineering Website: www.ijetae.com (E-ISSN 2250-2459, Scopus Indexed, ISO 9001:2008 Certified Journal, Volume 12, Issue 01, January 2022)

[15] O. Voitko, V. Loza, H. Khudov, V. Bakhvalov, I. Chernozubkin, N. Kuchuk, O. Oleksenko, M. Chepel, I. Khizhnyak, I. Yuzova. (2021). Peculiarities of Implementing the State's Strategic Narrative based on the Public Opinion. International Journal of Emerging Technology and Advanced Engineering, 11 (07), 48-59, https://doi.org/10.46338/ijetae0721_07

[16] Y.T. Yu, M.F. Lau, "A comparison of MC/DC, MUMCUT and several other coverage criteria for logical decisions", Journal of Systems and Software, 2005, in press.

[17] Honcharenko T., Tsiutsiura S., Kyivska K., Balina, O., Bezklubenko, I. (2021). Transform approach for formation of construction project management teams based on building information modeling. CEUR Workshop Proceedings, 2851, 11-21, http://ceur-ws.org/Vol2851/paper2.pdf

[18] Biloshchytskyi, A., Kuchansky, A., Andrashko, Y., Dubnytska, A., Vatskel, V. (2017). The method of the scientific directions potential forecasting in infocommunication systems of an assessment of the research activity results. 2017 4th International Scientific-Practical Conference Problems of Infocommunications Science and Technology, PIC S and T 2017 - Proceedings, 2018-January, c. 6972

[19] T. Honcharenko, G. Ryzhakova, Ye. Borodavka, D. Ryzhakov, V. Savenko, O. Polosenko. Method for representing spatial informationof topological relations based on a multidimensional data model, ARPN Journal of Engineering and Applied Sciences, vol. 16, $\begin{array}{llll}\text { Issue } 7, \quad 2021, & \text { 802-809, }\end{array}$ http://www.arpnjournals.org/jeas/research_papers/rp_2021/jeas_042 1_8555.pdf

[20] Bushuyev, S., Verenych, O. (2018). Organizational maturity and project: Program and portfolio success (Book Chapter). Developing Organizational Maturity for Effective Project Management, c. 104127

[21] Bushuyev, S.D., Bushuyev, D.A., Rogozina, V.B., Mikhieieva, O.V. (2015). Convergence of knowledge in project management. Proceedings of the 2015 IEEE 8th International Conference on Intelligent Data Acquisition and Advanced Computing Systems: Technology and Applications, IDAACS 2015, 2, 7341355, c. 496500 .

[22] M. Dyomin, A. Dmytrenko, D. Chernyshev, O. Ivashko, (2020). Big Cities Industrial Territories Revitalization Problems and Ways of Their Solution. Lecture Notes in Civil Engineering, vol. 73, pp. 365373.

[23] S. Azhar, A. Behringer, "A BIM-based approach for communicating and implementing a construction site safety plan" in 49th ASC Annual International Conference Proceedings, Associated Schools of Construction, 2013 https://ascpro0.ascweb.org/archives/cd/2013/paper/CPRT43002013. pdf
[24] Y. Tan, Y. Fang, T. Zhou, V.J.L. Gan, J.C.P. Cheng, "BIMsupported 4D acoustics simulation approach to mitigating noise impact on maintenance workers on offshore oil and gas platforms" in Automation In Construction, vol. 100, 1-10, 2019 https://doi.org/10.1016/j.autcon.2018.12.019

[25] Tkachenko, V., Kwilinski, A., Korystin, O., Svyrydiuk, N., Tkachenko, I. (2019). Assessment of information technologies influence on financial security of economy. Journal of Security and Sustainability Issues, 8(3), c. 375-385.

[26] J. K. W. Wong, and J. Zhou, "Enhancing environmental sustainability over building life cycles through green BIM: A review", Automation in Construction, vol. 57, pp. 156-165, 2015.

[27] A. H. Alavi, and A. H. Gandomi, "Big data in civil engineering. Automation in Construction", vol. 79, pp. 1-2, 2017

[28] Honcharenko T., Mihaylenko, V., Borodavka, Y., Dolya, E., Savenko, V. Information tools for project management of the building territory at the stage of urban planning, CEUR Workshop Proceedings, 2021, 2851, pp. 22-33, http://ceur-ws.org/Vol2851/paper3.pdf

[29] Ishchenko T., Chupryna, Y., Pokolenko, V. (2018). The organization of biosphere compatibility construction: Justification of the predictors of building development and the implementation prospects. International Journal of Engineering and Technology (UAE), 2018, 7(3), pp. 545-549.

[30] Tormosov, R., Chupryna, I., Ryzhakova, G., Pokolenko V., Prykhodko, D., Faizullin, A. (2021). Establishment of the rational economic and analytical basis for projects in different sectors for their integration into the targeted diversified program for sustainable energy development. SIST 2021 - 2021 IEEE International Conference on Smart Information Systems and Technologies, 9465993.

[31] Shpakov A., Zhaldak R., Kushnir I., Petrukha N., Nikolaev G., Rogovchenko V. (2021). Innovative and applied basis of structural and functional regulation of the operating management system of the leading stakeholders of the construction project. Management of Development of Complex Systems, 47, pp. 151-161, dx.doi.org\10.32347/2412-9933.2021.47.151-161

[32] Kucherenko O., Ryzhakova G., Chupryna K., Shpakova H., Kishchak N., Veremeev Serhii. (2021). Scientific and applied components of the formation of the strategy of institutional-oriented diversification of construction enterprises. Management of development of complex systems, 47, pp. 109-118; dx.doi.org $\backslash 10.32347 / 2412-9933.2021 .47 .109-118$

[33] Ryzhakova, G. M., Ryzhakov, D. A., Shpakova, G. V. (2018). Provision of economic-reproductive and analytical controlling functions of tools for asset management of housing developers. Ways to increase the efficiency of construction in the formation of market relations, 38, 36-44. URL: http://nbuv.gov.ua/UJRN/shpebfrv_2018_38_6 